Western University

Scholarship@Western

Chemistry Publications

Chemistry Department

2017

Synthesis, properties, and degradation of polyisobutylene-polyester graft copolymers

Bethany A. Turowec

Western University

Elizabeth R. Gillies

Western University, egillie@uwo.ca

Follow this and additional works at: https://ir.lib.uwo.ca/chempub

Part of the Chemistry Commons

Citation of this paper:

Turowec, Bethany A. and Gillies, Elizabeth R., "Synthesis, properties, and degradation of polyisobutylene-polyester graft copolymers" (2017). Chemistry Publications. 106.

https://ir.lib.uwo.ca/chempub/106 


\section{Synthesis, properties, and degradation of polyisobutylene-polyester graft copolymers}

Bethany A. Turowec ${ }^{\&}$ and Elizabeth R. Gillies ${ }^{\# *}$

${ }^{\&}$ Biomedical Engineering Graduate Program, The University of Western Ontario, 1151

Richmond St., London, Canada N6A 5B9

\#Department of Chemical and Biochemical Engineering, The University of Western Ontario, 1151 Richmond St., London, Canada N6A 5B9

${ }^{\$}$ Department of Chemistry and Center for Advanced Materials and Biomaterials Research (CAMBR), The University of Western Ontario, 1151 Richmond St., London, Canada N6A 5B7

Keywords: polyisobutylene, butyl rubber, poly(lactic acid), polycaprolactone, graft copolymer

*Author to whom correspondence should be addressed: egillie@uwo.ca; 1151 Richmond St., London, Canada, N6A $5 \mathrm{~B} 7$ 


\begin{abstract}
The development of copolymers is a promising approach for combining the favorable properties of two polymers and obtaining new properties of the combination. In this work, graft copolymers of polyisobutylene (PIB) and polycaprolactone (PCL) or poly(D,L-lactide) (PDLLA) were synthesized and studied. Amine terminated polyesters were synthesized and were grafted onto an activated PIB backbone synthesized from butyl rubber, a copolymer of isobutylene and 2 mol \% isoprene. The polyester content was tuned from 15 to $44 \mathrm{wt} \%$ by varying the molar mass of the polyester blocks and the number of molar equivalents used in the grafting reaction. The graft copolymers with higher polyester content underwent nanoscale phase separation, as demonstrated by differential scanning calorimetry and atomic force microscopy imaging. This was found to provide enhanced mechanical properties such as increased tensile strength and Young's modulus relative to the starting rubber or physical blends. Despite the significant polyester content of the graft copolymers and the susceptibility of the polyesters to degradation, the graft copolymers underwent negligible mass loss in $5 \mathrm{M} \mathrm{NaOH}$ over a period of 8 weeks. These results suggest that polyesters can be incorporated into PIB to tune and enhance its properties, while maintaining high chemical stability.
\end{abstract}




\section{Introduction}

Polyisobutylene (PIB) and butyl rubber, a copolymer composed primarily of isobutylene with small percentages of isoprene, exhibit many favorable properties including excellent impermeability to water and gases, high chemical stability, high damping, and high elasticity. ${ }^{1,2}$ These properties have enabled its use in a wide range of commercial applications including automobile tires, sporting equipment, adhesives, sealants, and chewing gum. In many applications, butyl rubber is covalently cross-linked through its isoprene units or halogenated derivatives in order to afford increased modulus, resilience, and creep resistance. ${ }^{3-5}$ However, this method of cross-linking is generally limited to applications where the potential leaching of chemical additives is not a major concern and where the rubber can be permanently cast in its desired form prior to the application. To broaden the scope of butyl rubber that is cross-linked through covalent bonds, additive-free cross-linking using pendant cinnamate groups was reported $^{6}$ and thermo-reversible approaches have also been described. ${ }^{7,8}$

Another approach to tuning the properties of PIB and butyl rubber has involved the preparation of block copolymers. For example, graft copolymers having pendant poly(ethylene oxide), ${ }^{9-16}$ polystyrene, ${ }^{7,17}$ and polyethylene ${ }^{10}$ chains have been synthesized and incorporation of the grafts has been shown to provide changes in the thermal and mechanical properties as well as new functions such as resistance to protein adsorption and the ability to self-assemble into micellar morphologies in aqueous solution. Networks and gels based on PIB with poly $(N-$ isopropylacrylamide) ${ }^{18}$, poly(methyl methacrylate), ${ }^{19}$ and poly(methacrylic acid) ${ }^{20}$ have also been prepared and studied. Many more efforts have focused on the synthesis of linear multi-block copolymers containing PIB segments. For example, block copolymers containing PIB as well as polystyrenes, ${ }^{21-27}$ poly(acrylic acid),${ }^{28,29}$ polyamide, ${ }^{30}$ polypivalolactone, ${ }^{31}$ poly(methyl 
methacrylate),${ }^{32}$ poly $(N \text {-isopropylacrylamide })^{33}$ polyurethanes, ${ }^{34,35}$ and polyalloocimene ${ }^{36,37}$ have been synthesized and studied. Many of these PIB-based block copolymers incorporated glassy or semi-crystalline blocks, enabling them to behave as thermoplastic elastomers. Below their glass transition temperature $\left(\mathrm{T}_{\mathrm{g}}\right)$ or melting temperature $\left(\mathrm{T}_{\mathrm{m}}\right)$, these blocks can provide physical crosslinking through phase separation. This allows the materials to behave as cross-linked rubbers at room temperature, yet they melt like plastics above the $T_{g}$ or $T_{m}$ and can dissolve in solvents, facilitating their processing by thermal or solution methods. A poly(styrene- $b$-isobutylene- $b$ styrene) (SIBS) copolymer has been successfully used as a paclitaxel-eluting coating on the commercial TAXUS Express $2^{\mathrm{TM}}$ coronary stent. ${ }^{38,39}$ Nevertheless, there is still significant interest in optimizing and tuning the properties of PIB-based materials for different applications. ${ }^{40}$

Aliphatic polyesters such as polylactide (PLA) and polycaprolactone (PCL) are increasingly used in a wide range of applications including 3D printing, food and beverage containers, and medical implants. They are attractive as they can be broken down in the environment and in vivo to non-toxic products and have been demonstrated to be biocompatible in a variety of applications. ${ }^{41,42} \mathrm{PCL}$, as well as two of PLA's stereochemical forms (poly-Dlactide and poly-L-lactide) are semicrystalline materials, exhibiting $\mathrm{T}_{\mathrm{g} S}$ of $-60{ }^{\circ} \mathrm{C}, 55^{\circ} \mathrm{C}$ and 60 $65{ }^{\circ} \mathrm{C}$, and $\mathrm{T}_{\mathrm{m}} \mathrm{s}$ of $59-64{ }^{\circ} \mathrm{C}, 150-170{ }^{\circ} \mathrm{C}$ and $175{ }^{\circ} \mathrm{C}$, respectively. ${ }^{43-45} \mathrm{~A}$ third stereochemical form of PLA, poly-D,L-lactide (PDLLA), is amorphous and exhibits a $T_{g}$ of approximately 55-60 ${ }^{\circ} \mathrm{C}$. The degradation rates of these polymers are influenced by their thermal properties as well as their molar masses and chain-end functional groups. While the thermal properties of PLA and PCL offer the possibility to obtain thermoplastic elastomer properties with PIB and butyl rubber, very limited research has been conducted on the preparation and study of such copolymers with PCL or PLA. Linear multiblock copolymers of PIB and PLLA ${ }^{46,47}$ or PCL ${ }^{48-51}$ have been 
prepared and studied. However, to the best of our knowledge, there is only one prior report of a graft copolymer prepared from butyl rubber and PCL. In this case, the grafting reaction proceeded in low yield with only $\sim 10 \%$ of the derivatized isoprene units functionalized with PCL and a maximum PCL content of 9-12 wt \%. ${ }^{10}$

Utilizing our efficient chemistry for the preparation of graft copolymers from butyl rubber, ${ }^{13,14}$ we report here the synthesis and study of graft copolymers with PCL and PDLLA. While PCL is semi-crystalline, the PDLLA stereochemical form of PLA is selected in order to study the influence of a glassy block. Different polyester content is achieved in the graft copolymers by starting with different molar masses of polyesters and also by tuning the ratio of polyester to activated functional groups on the RB backbone. The thermal properties, phase separation behavior, mechanical, and degradation properties of the polymers are studied in order to elucidate structure-property relationships for these materials.

\section{Experimental section}

\section{General procedures and materials}

Butyl rubber 402 containing $2 \mathrm{~mol} \%$ isoprene units $\left(\mathrm{M}_{\mathrm{w}}=395 \mathrm{~kg} \mathrm{~mol}^{-1}\right.$; dispersity $(\nexists)=2.44$, as measured by size exclusion chromatography (SEC) in tetrahydrofuran (THF) relative to polystyrene standards) was provided by LANXESS (Sarnia, Canada) and was converted to the 4nitrophenyl carbonate derivative (PIB-PNP) by the previously reported method. ${ }^{13}$ Hydroxylterminated PCL with an $\mathrm{M}_{\mathrm{n}}$ of $900 \mathrm{~g} \mathrm{~mol}^{-1}$ (PCL-OH-900) and $3500 \mathrm{~g} \mathrm{~mol}^{-1}$ (PCL-OH-3500) and hydroxyl-terminated PDLLA with an $\mathrm{M}_{\mathrm{n}}$ of $2800 \mathrm{~g} \mathrm{~mol}^{-1}$ (PDLLA-OH-2800) were purchased from Polymer Source (Montreal, Canada). Their $\mathrm{M}_{\mathrm{n}} \mathrm{s}$ and $\oslash$ measured by SEC in THF relative to polystyrene standards were $\mathrm{M}_{\mathrm{n}}=1870 \mathrm{~g} \mathrm{~mol}^{-1}$ and $D=1.3, \mathrm{M}_{\mathrm{n}}=7620 \mathrm{~g} \mathrm{~mol}^{-1}$ and $\oslash=$ 
1.2 , and $\mathrm{M}_{\mathrm{n}}=3850 \mathrm{~g} \mathrm{~mol}^{-1}$ and $\oslash=1.2$ for PCL-OH-900, PCL-OH-3500, and PDLLA-OH-

2800 respectively. Silicon wafers were purchased from University Wafer (Boston, Massachusetts). Solvents were purchased from Caledon (Georgetown, ON, Canada) and 4nitrophenyl chloroformate was purchased from Alfa Aesar (Ward Hill, MA, USA). Dry $\mathrm{CH}_{2} \mathrm{Cl}_{2}$ and toluene were obtained from an Innovative Technology (Newburyport, USA) solvent purification system based on aluminum oxide columns. All other chemicals were purchased from Sigma Aldrich (St. Louis, MO, USA) and used without further purification unless stated otherwise. Nuclear magnetic resonance (NMR) spectra were obtained in $\mathrm{CDCl}_{3}$ using a $400 \mathrm{MHz}$ or $600 \mathrm{MHz}$ Varian Inova spectrometer. NMR chemical shifts are reported in ppm and are calibrated against residual solvent signals of $\mathrm{CDCl}_{3}(\delta$ 7.26). Coupling constants $(\mathrm{J})$ are reported in Hz. Differential scanning calorimetry (DSC) was performed under a nitrogen atmosphere on a Q20 DSC from TA Instruments (Newcastle, DE, USA) at a heating/cooling rate of $10^{\circ} \mathrm{C} / \mathrm{min}$ from -100 to $+100{ }^{\circ} \mathrm{C}$. The $\mathrm{T}_{\mathrm{g}}$ and $\mathrm{T}_{\mathrm{m}}$ were obtained from the second heating cycle. SEC was performed in THF using a Viscotek GPCmax VE 2001 GPC Solvent/Sample Module equipped with a Waters 2489 UV/Visible Detector, Viscotek VE 3580 RI Detector and two PolyPore (300 $\mathrm{mm} \times 7.5 \mathrm{~mm}$ ) columns from Agilent. The calibration was performed using polystyrene standards. Fourier transform infrared spectroscopy (FTIR) was performed on a Bruker Optics TENSOR 27 series FTIR, OPUS 7.0, recording from $500-3700 \mathrm{~cm}^{-1}$.

\section{Synthesis of PCL-NHBOC-900}

PCL-OH-900 ( $0.40 \mathrm{~g}, 0.44 \mathrm{mmol}, 1.0$ equiv.), 4-(dimethylamino)pyridine (DMAP) (0.20 g, 1.6 mmol, 3.7 equiv.), pyridine ( $0.10 \mathrm{~g}, 1.3 \mathrm{mmol}, 2.9$ equiv.) were dissolved in dry $\mathrm{CH}_{2} \mathrm{Cl}_{2}(7 \mathrm{~mL})$. BOC-protected $\beta$-alanine anhydride ${ }^{52}(0.39 \mathrm{~g}, 1.1 \mathrm{mmol}, 2.5$ equiv. $)$ was dissolved separately in 
dry $\mathrm{CH}_{2} \mathrm{Cl}_{2}(2 \mathrm{~mL})$ then was added to the PCL solution and stirred overnight at room temperature. Next, deionized water was added to the reaction mixture and it was stirred for an additional 3 hours at room temperature. The product was isolated by washing the organic phase with $1 \mathrm{M} \mathrm{HCl}$ (3 times), $1 \mathrm{M} \mathrm{Na}_{2} \mathrm{CO}_{3}$ (3 times) and then concentrated brine (1 time). The $\mathrm{CH}_{2} \mathrm{Cl}_{2}$ was then dried with $\mathrm{MgSO}_{4}$, filtered, and the solvent was removed in vacuo. Yield: $0.35 \mathrm{~g}, 83 \%$. ${ }^{1} \mathrm{H}$ NMR (400 MHz, $\left.\mathrm{CDCl}_{3}\right): \delta 4.24(\mathrm{t}, 2 \mathrm{H}, \mathrm{J}=4.7 \mathrm{~Hz}), 4.05(\mathrm{t}, 18 \mathrm{H}, \mathrm{J}=6.0 \mathrm{MHz}), 3.70(\mathrm{t}, 2 \mathrm{H}, \mathrm{J}$ $=5.1 \mathrm{~Hz}), 3.63-3.66(\mathrm{~m}, 2 \mathrm{H}), 3.54-3.56(\mathrm{~m}, 2 \mathrm{H}), 3.39(\mathrm{~s}, 3 \mathrm{H}), 2.51(\mathrm{t}, 2 \mathrm{H}, \mathrm{J}=6.1 \mathrm{~Hz}), 2.29-2.37$ $(\mathrm{m}, 16 \mathrm{H}), 1.60-1.69(\mathrm{~m}, 32 \mathrm{H}), 1.43(\mathrm{~s}, 9 \mathrm{H}), 1.34-1.42(\mathrm{~m}, 16 \mathrm{H}) . \mathrm{SEC}: \mathrm{M}_{\mathrm{w}}=3160 \mathrm{~g} \mathrm{~mol}^{-1}, Ð=$ 1.33. FTIR: $1047,1105,1171,1246,1366,1420,1472,1569,1728,2947,2866,3393,3439 \mathrm{~cm}^{-}$ 1.

\section{Synthesis of PCL-NH2-900}

PCL-NHBOC-900 (0.34 g, $0.37 \mathrm{mmol}, 1.0$ equiv.) was dissolved in $2.5 \mathrm{~mL}$ of 1:1 trifluoroacetic acid (TFA): $\mathrm{CH}_{2} \mathrm{Cl}_{2}(1: 1)$ and the reaction mixture was stirred for 2 hours. The solvents were removed under a stream of air in the fumehood. The product was redissolved in $\mathrm{CH}_{2} \mathrm{Cl}_{2}$ and dried in vacuo to remove residual TFA, providing the product as its TFA salt. Yield: $0.34 \mathrm{~g},>99 \% .{ }^{1} \mathrm{H}$ NMR (400 MHz, $\left.\mathrm{CDCl}_{3}\right): \delta 4.24(\mathrm{t}, 2 \mathrm{H}, \mathrm{J}=4.7 \mathrm{~Hz}), 4.16(\mathrm{t}, 2 \mathrm{H}, \mathrm{J}=6.4 \mathrm{~Hz}), 4.06(\mathrm{t}, 16 \mathrm{H}, \mathrm{J}=6.6$ Hz), 3.85 (br s, 3H), $3.70(\mathrm{t}, 2 \mathrm{H}, \mathrm{J}=4.7 \mathrm{~Hz}), 3.64-3.66(\mathrm{~m}, 2 \mathrm{H}), 3.55-3.58(\mathrm{~m}, 2 \mathrm{H}), 3.39(\mathrm{~s}, 3 \mathrm{H})$, 3.33 (br s, 2H), 2.80 (t, 2H, J = 5.9 Hz), 2.29-2.34 (m, 16H), 1.60-1.69 (m, 32H), 1.34-1.42 (m, 16H). SEC: $\mathrm{M}_{\mathrm{n}}=1690 \mathrm{~g} \mathrm{~mol}^{-1}, Ð=1.45$. FTIR: 1047, 1105, 1171, 1246, 1366, 1420, 1472 , $1569,1728,2947,2866,3445 \mathrm{~cm}^{-1}$.

\section{Synthesis of PCL-NHBOC-3500}

The same procedure described above for the synthesis of PCL-NHBOC-900 was followed except that PCL-OH-3500 (0.40 g, 0.11 mmol, 1.0 equiv.) was used. Yield: $0.38 \mathrm{~g}, 88 \%$. ${ }^{1} \mathrm{H}$ 
NMR (400 MHz, $\left.\mathrm{CDCl}_{3}\right): \delta 4.13(\mathrm{td}, 2 \mathrm{H}, \mathrm{J}=7.8,4.7 \mathrm{~Hz}), 4.06(\mathrm{t}, 52 \mathrm{H}, \mathrm{J}=6.8 \mathrm{~Hz}), 3.37-3.41(\mathrm{~m}$, 2H), $2.51(\mathrm{t}, 2 \mathrm{H}, \mathrm{J}=6.1 \mathrm{~Hz}), 2.30(\mathrm{t}, 54 \mathrm{H}, \mathrm{J}=7.4 \mathrm{~Hz}), 1.62-1.68(\mathrm{~m}, 108 \mathrm{H}), 1.34-1.43(\mathrm{~m}, 62 \mathrm{H})$, $1.25(\mathrm{t}, 3 \mathrm{H}, \mathrm{J}=7 \mathrm{~Hz}) . \mathrm{SEC}: \mathrm{M}_{\mathrm{n}}=7540 \mathrm{~g} \mathrm{~mol}^{-1}, Ð=1.22$. FTIR: 1047, 1105, 1171, 1246, 1366, $1420,1472,1569,1728,2947,2866,3393,3439 \mathrm{~cm}^{-1}$.

\section{Synthesis of PCL-NH2-3500}

The same procedure described above for the synthesis of PCL-NH2-900 was followed except that PCL-NHBOC-3500 (0.40 g, 0.11 mmol, 1.0 equiv.) was used. Yield: 0.40 g, > $99 \%$ \%. ${ }^{1} \mathrm{H}$ NMR $\left(400 \mathrm{MHz}, \mathrm{CDCl}_{3}\right): \delta 4.17(\mathrm{t}, 2 \mathrm{H}, \mathrm{J}=6.5 \mathrm{~Hz}), 4.10-4.15(\mathrm{~m}, 2 \mathrm{H}), 4.06(\mathrm{t}, 76 \mathrm{H}, \mathrm{J}=6.5 \mathrm{~Hz}), 3.33$ $(\mathrm{t}, 2 \mathrm{H}, \mathrm{J}=5.9 \mathrm{~Hz}), 2.83(\mathrm{t}, 2 \mathrm{H}, \mathrm{J}=5.3 \mathrm{~Hz}), 2.31(\mathrm{t}, 80 \mathrm{H}, \mathrm{J}=7.6 \mathrm{~Hz}), 1.62-1.68(\mathrm{~m}, 162 \mathrm{H}), 1.36-$ $1.41(\mathrm{~m}, 80 \mathrm{H}), 1.25(\mathrm{t}, 3 \mathrm{H}, \mathrm{J}=7.6 \mathrm{~Hz}) . \mathrm{SEC}: \mathrm{M}_{\mathrm{n}}=7400 \mathrm{~g} \mathrm{~mol}^{-1}, \bigoplus=1.22$. FTIR: 1047,1105 , $1171,1246,1366,1420,1472,1569,1728,2947,2866,3445 \mathrm{~cm}^{-1}$.

\section{Synthesis of PDLLA-NHBOC-2800}

The same procedure described above for the synthesis of PCL-NHBOC-900 was followed except that PDLLA-OH-2800 (0.40 g, 0.14 mmol, 1.0 equiv.) was used. Yield: $0.31 \mathrm{~g}, 81 \% .{ }^{1} \mathrm{H}$ NMR (400 MHz, $\left.\mathrm{CDCl}_{3}\right): \delta$ 5.12-5.25 (m, 39H), 4.23-4.32 (m, 2H), 3.56-3.60 (m, 2H), 3.44 (br $\mathrm{s}, 2 \mathrm{H}), 3.36(\mathrm{~s}, 3 \mathrm{H}), 2.56-2.61(\mathrm{~m}, 2 \mathrm{H}), 1.54-1.59(\mathrm{~m}, 117 \mathrm{H}), 1.43(\mathrm{~s}, 9 \mathrm{H})$. SEC: $\mathrm{M}_{\mathrm{n}}=4280 \mathrm{~g}$ $\mathrm{mol}^{-1}, Ð=1.19$. FTIR: 1134, 1267, 1512, 1757, 2949, 2997, 3517, $3435 \mathrm{~cm}^{-1}$.

\section{Synthesis of PDLLA-NH2-2800}

PDLLA-NHBOC-2800 was dissolved in $2 \mathrm{~mL}$ of dry $\mathrm{CH}_{2} \mathrm{Cl}_{2}$. TFA was added $(0.70 \mathrm{~g}, 6.1$ mmol, 100 equiv.) and the reaction mixture was stirred at $0{ }^{\circ} \mathrm{C}$ for 2 hours. Next, the solvents were removed under reduced pressure ( $\sim 20$ mbar). The product was re-dissolved in $\mathrm{CH}_{2} \mathrm{Cl}_{2}$ and then passed over a $\mathrm{K}_{2} \mathrm{CO}_{3}$ plug to remove residual TFA, affording the product as the free amine. Yield: 0.65 g, 91 \%. ${ }^{1} \mathrm{H}$ NMR: $\delta, 5.13-5.23$ (m, 39H), 4.23-4.32 (m, 2H), 3.56-3.58 (m, 2H), 3.36 
(s, 3H), 3.29 (br s, 2H), 2.83 (br s, 2H), 1.54-1.58 (m, 117H). SEC: $\mathrm{M}_{\mathrm{n}}=3620 \mathrm{~g} \mathrm{~mol}^{-1}, Ð=1.31$.

IR: $1134,1267,1512,1757,2949,2997,3508 \mathrm{~cm}^{-1}$.

\section{Synthesis of PIB-PCL-900}

PCL-NH2-900 (0.95 g, $1.1 \mathrm{mmol}, 1.2$ equiv.) was dissolved in $20 \mathrm{~mL}$ of dry toluene at $60{ }^{\circ} \mathrm{C}$. A solution of PIB-PNP ${ }^{13}$ (2.2 g, $0.88 \mathrm{mmol}$ of 4-nitrophenylcarbonate units, 1.0 equiv.) in $25 \mathrm{~mL}$ of dry toluene was added dropwise to the reaction mixture. DMAP $(0.43 \mathrm{~g}, 3.52 \mathrm{mmol}, 4.0$ equiv.) dissolved in $4 \mathrm{~mL}$ dry toluene was also added to the reaction mixture, which was then stirred overnight at $60^{\circ} \mathrm{C}$. The solvent was then removed in vacuo and the graft copolymer was redissolved in $\mathrm{CH}_{2} \mathrm{Cl}_{2}$, washed with deionized water (3 times), dried with $\mathrm{MgSO}_{4}$, filtered, concentrated and precipitated from $\mathrm{CH}_{2} \mathrm{Cl}_{2}$ into acetone to afford the product. Yield: $2.45 \mathrm{~g}, 85$ \%. ${ }^{1} \mathrm{H}$ NMR (600 MHz, $\left.\mathrm{CDCl}_{3}\right): \delta 5.20$ (br s, 0.32H), $5.10(\mathrm{~s}, 0.52 \mathrm{H}), 5.05(\mathrm{~s}, 0.37 \mathrm{H}), 4.87$ (s, $0.44 \mathrm{H}), 4.24(\mathrm{t}, 1 \mathrm{H}, \mathrm{J}=5.3 \mathrm{~Hz}), 4.06(\mathrm{t}, 7.94 \mathrm{H}, \mathrm{J}=6.5 \mathrm{~Hz}), 3.70(\mathrm{t}, 0.99 \mathrm{H}, \mathrm{J}=4.7 \mathrm{~Hz}), 3.60-3.65$ $(\mathrm{m}, 0.96 \mathrm{H}), 3.54-3.56(\mathrm{~m}, 0.88 \mathrm{H}), 3.45(\mathrm{q}, 1.13 \mathrm{H}, \mathrm{J}=5.9 \mathrm{~Hz}), 3.38(\mathrm{~s}, 1.19 \mathrm{H}), 2.53(\mathrm{t}, 1.07 \mathrm{H}, \mathrm{J}=$ $6.2 \mathrm{~Hz}), 2.3(\mathrm{t}, 9.31 \mathrm{H}, \mathrm{J}=7.6 \mathrm{~Hz}), 1.62-1.68(\mathrm{~m}, 38 \mathrm{H}), 1.41(\mathrm{~s}, 107 \mathrm{H}), 1.11(\mathrm{~s}, 294 \mathrm{H})$. PCL content from ${ }^{1} \mathrm{H}$ NMR $=15 \mathrm{wt} \%$. IR: 1165, 1230, 1366, 1390, 1470, 1736, 2955, $3445 \mathrm{~cm}^{-1}$. DSC: $\mathrm{T}_{\mathrm{g}}=-67^{\circ} \mathrm{C}$.

\section{Synthesis of PIB-PCL-3500a}

An analogous procedure to that described above for the synthesis of PCL-NHBOC-900 was followed except that the following reagents were used: PCL-NH2-3500 $(0.71 \mathrm{~g}, 0.20$ mmol, 0.8 equiv.); PIB-PNP (0.63 g, $0.25 \mathrm{mmol}$ of 4-nitrophenylcarbonate units, 1.0 equiv.); DMAP (0.12 g, 1.0 mmol, 4.0 equiv.). Yield: $1.2 \mathrm{~g}, 89 \% .{ }^{1} \mathrm{H}$ NMR (600 MHz, $\left.\mathrm{CDCl}_{3}\right): \delta 5.27(\mathrm{~s}, 0.24 \mathrm{H}), 5.20$

(br. s, 0.16H), $5.12(\mathrm{~s}, 0.28 \mathrm{H}), 5.10(\mathrm{~s}, 0.14 \mathrm{H}), 5.05(\mathrm{~s}, 0.18 \mathrm{H}), 4.87(\mathrm{~s}, 0.25 \mathrm{H}), 4.13(\mathrm{q}, 0.5 \mathrm{H}, \mathrm{J}=$ $7.2 \mathrm{~Hz}), 4.07(\mathrm{t}, 16.5 \mathrm{H}, \mathrm{J}=6.5 \mathrm{~Hz}), 3.45(\mathrm{q}, 0.28 \mathrm{H} \mathrm{J}=5.9 \mathrm{~Hz}), 2.53(\mathrm{t}, 0.43 \mathrm{H}, \mathrm{J}=5.9 \mathrm{~Hz}), 2.31$ 
(t, 16.6H, J = 7.3 Hz), 1.62-1.68 (m, 33.8H), $1.41(\mathrm{~s}, 115 \mathrm{H}), 1.11(\mathrm{~s}, 294 \mathrm{H})$. PCL content from ${ }^{1} \mathrm{H}$ $\mathrm{NMR}=26$ wt \%. IR: 1165, 1230, 1366, 1390, 1470, 1736, 2955, $3445 \mathrm{~cm}^{-1} . \mathrm{DSC}: \mathrm{T}_{\mathrm{g}}=-65^{\circ} \mathrm{C}$, $\mathrm{T}_{\mathrm{m}}=44^{\circ} \mathrm{C}$.

\section{Synthesis of PIB-PCL-3500b}

An analogous procedure to that described above for the synthesis of PCL-NHBOC-900 was followed except that the following reagents were used: PCL-NH2-3500 (0.34 g, 0.097 mmol, 1.2 equiv.); PIB-PNP (0.20 g, $0.082 \mathrm{mmol}$ of 4-nitrophenylcarbonate units, 1.0 equiv.); DMAP (40 mg, 0.32 mmol, 4.0 equiv.). Yield: 0.24 g, $51 \%$. ${ }^{1} \mathrm{H}$ NMR: $\delta 5.19$ (br. s, $\left.0.22 \mathrm{H}\right), 5.1$ (s, $\left.0.44 \mathrm{H}\right)$, 5.05 (br. s, $0.33 \mathrm{H}), 4.87$ (br. s, $0.46 \mathrm{H}), 4.13$ (q, 1.1H, J = 7.2 Hz), 4.07 (t, 36.5H, J = 6.5 Hz), $3.46(\mathrm{q}, 0.94 \mathrm{H}, \mathrm{J}=5.9 \mathrm{~Hz}), 2.53(\mathrm{t}, 0.97 \mathrm{H}, \mathrm{J}=5.9 \mathrm{~Hz}), 2.31(\mathrm{t}, 37.4 \mathrm{H}, \mathrm{J}=7.3 \mathrm{~Hz}), 1.62-1.68(\mathrm{~m}$, 118H), $1.41(\mathrm{~s}, 134 \mathrm{H}), 1.11(\mathrm{~s}, 294 \mathrm{H})$. PCL content from ${ }^{1} \mathrm{H}$ NMR $=44$ wt \%. IR: 1165, 1230, $1366,1390,1470,1736,2955,3445 \mathrm{~cm}^{-1}$. DSC: $\mathrm{T}_{\mathrm{g}}=-62{ }^{\circ} \mathrm{C}, \mathrm{T}_{\mathrm{m}}=50^{\circ} \mathrm{C}$.

\section{Synthesis of PIB-PDLLA-2800}

An analogous procedure to that described above for the synthesis of PCL-NHBOC-900 was followed except that the following reagents were used: PDLLA-NH -3500 (0.65 g, 0.23 mmol, 1.2 equiv.); PIB-PNP (0.48 g, $0.19 \mathrm{mmol}$ of 4-nitrophenylcarbonate units, 1.0 equiv.); DMAP (90 mg, 0.77 mmol, 4.0 equiv.). Yield: 0.51 g, $50 \%$. ${ }^{1} \mathrm{H}$ NMR: $\delta$ 5.14-5.25 (m, 14.8H), 5.11 (br. s, 0.48H), 5.04 (br. s, 0.31H), $4.86(\mathrm{~s}, 0.36 \mathrm{H}), 4.23-4.32(\mathrm{~m}, 1.09 \mathrm{H}), 3.57-3.59(\mathrm{~m}, 0.97 \mathrm{H}), 3.45-$ $3.50(\mathrm{~m}, 1.31 \mathrm{H}), 3.36(\mathrm{~s}, 1.27 \mathrm{H}), 2.61(\mathrm{t}, 1.11 \mathrm{H}, \mathrm{J}=2 \mathrm{~Hz}), 1.54-1.59(\mathrm{~m}, 65.9 \mathrm{H}), 1.41(\mathrm{~s}, 96 \mathrm{H})$ $1.11(\mathrm{~s}, 293 \mathrm{H})$. PDLLA content from ${ }^{1} \mathrm{H}$ NMR $=46 \mathrm{wt} \%$. IR: 1094, 1132, 1188, 1365, 1388, $1468,1757,2896,2952 \mathrm{~cm}^{-1}$. DSC: $\mathrm{T}_{\mathrm{g} 1}=-63{ }^{\circ} \mathrm{C} ; \mathrm{T}_{\mathrm{g} 2}=23{ }^{\circ} \mathrm{C}$. 


\section{Atomic force microscopy (AFM)}

Silicon wafers were cut into small pieces $\left(\sim 1 \mathrm{~cm}^{2}\right)$ and treated with "Piranha" solution, a mixture of 3:1 $\mathrm{H}_{2} \mathrm{SO}_{2}: \mathrm{H}_{2} \mathrm{O}_{2}$ for approximately 1 hour to generate a clean, hydrophilic surface. The surface was then cleaned with deionized water, acetone and subsequently dried overnight in a desiccator. Polymer thin films were prepared by spin-coating $100 \mu \mathrm{L}$ of a $3 \mathrm{wt} \%$ solution of the material in toluene on $1 \mathrm{~cm}^{2}$ of silicon wafer at $6000 \mathrm{rpm}$ for 30 seconds. The surfaces were kept under vacuum for at least 24 hours prior to image analysis. Annealing was performed by heating the samples at $100{ }^{\circ} \mathrm{C}$ for 7 hours in a vacuum oven. Surfaces were visualized by an AFM (XE-100 microscope from PSIA). Images were obtained by scanning surfaces in tapping mode with rectangular-shaped silicon cantilevers with a spring constant of $48 \mathrm{~N} / \mathrm{m}$. Images were then refined using XEI Image Processing software for SPM data by applying surface smoothing and glitch removal.

\section{Water contact angle analysis}

Polymer coatings on silicon wafers were prepared as described above for the AFM imaging. The water contact angle of the polymer film surface in air was measured by using a sessile drop method on a KRÜSS DSA100 Drop Shape Analysis System (Hamburg, Germany). Timing started after dosing a water droplet onto the testing surface, allowing for an incubation period of 30 seconds for consistency. After 30 seconds, angles were recorded via tangent analysis.

\section{Tensile testing}

A $40 \mathrm{~mm}$ x $5 \mathrm{~mm}$ x $0.3 \mathrm{~mm}$ (length $\mathrm{x}$ width $\mathrm{x}$ thickness) strip of polymer was cut from a polymer film (prepared via compression-molding with Carver Model 385-OC heated manual press) and its tensile properties were measured on an Instron 3365 universal testing instrument, at $25 \mathrm{~mm} / \mathrm{min}$ 
and $25^{\circ} \mathrm{C}$, in accordance with ASTM D882 - 12. For each copolymer, at least 6 samples were tested in separate analyses, and the data reported is the calculated mean \pm standard deviation.

\section{Degradation study}

Sample preparation: Graft copolymers and control materials were compression-moulded using a Carver Model 385-OC (Carver Inc., Wabash) heated manual press into films approximately 0.35 $\mathrm{mm}$ in thickness. Disks having a diameter of $5 \mathrm{~mm}$ were punched out of the films. Each disk weighed approximately $5 \mathrm{mg}$ and the exact mass was accurately recorded.

Degradation: Pre-weighed disks ( 3 per time point) were each immersed in $1 \mathrm{~mL}$ of $5 \mathrm{M} \mathrm{NaOH}$ and the vials were sealed and then incubated in an oven at $37^{\circ} \mathrm{C}$. At each point, 3 disks were removed, rinsed with deionized water and dried in a vacuum oven at $37^{\circ} \mathrm{C}$ for $24 \mathrm{~h}$. Dried disks were weighed to determine $\%$ mass loss according to equation 1 ,

$$
\% \text { Mass Loss }=\left(\frac{m_{i}-m_{t}}{m_{i}}\right) \times 100 \%
$$

where $m_{i}$ is the initial disk mass and $m_{t}$ is mass of the disk at time t. The data reported is the calculated mean \pm standard deviation for the triplicate samples.

\section{Scanning electron microscopy}

SEM micrographs were obtained using a Hitachi 3400-N Variable Pressure Scanning Electron Microscope. Images were taken at $100 \mathrm{X}$ and $1000 \mathrm{X}$ magnification utilizing variable pressure mode to avoid sample preparation via gold sputtering techniques (possible damage to rubber films).

\section{Results and discussion}




\section{Synthesis and chemical characterization of graft copolymers}

A "grafting-to" synthetic approach was used for the preparation of the PIB-polyester block copolymers. First, amine-terminated PCL and PDLLA were prepared. As shown in Scheme 1, hydroxyl-terminated PCL with a number average molar mass $\left(\mathrm{M}_{\mathrm{n}}\right)$ of either $900 \mathrm{~g} \mathrm{~mol}^{-1}$ (PCLOH-900) or $3500 \mathrm{~g} \mathrm{~mol}^{-1}$ (PCL-OH-3500) was reacted with an anhydride derivative of tertbutyloxycarbonyl ( $t$-BOC)-protected $\beta$-alanine ${ }^{52}$ in the presence of pyridine and 4 dimethylaminopyridine (DMAP) as a catalyst to provide the protected polymers PCL-NHBOC900 and PCL-NHBOC-3500. The BOC protecting group was then removed using trifluoracetic acid (TFA) to afford the target amine-functionalized polymers PCL-NH2-900 and PCL-NH23500 in the form of their TFA salts. The same approach was used to prepare amine-terminated PDLLA from a starting hydroxyl-terminated PDLLA with an $\mathrm{M}_{\mathrm{n}}$ of $2800 \mathrm{~g} \mathrm{~mol}^{-1}$ (PDLLA-OH2800) (Scheme 2). However, the target polymer PDLLA-NH2-2800 was more prone to cleavage of the terminal $\beta$-alanine moiety from the polymer under acidic conditions, so it was necessary to perform the TFA deprotection under anhydrous conditions at $0{ }^{\circ} \mathrm{C}$ and to pass the resulting polymer over a $\mathrm{K}_{2} \mathrm{CO}_{3}$ plug in order to afford the free base form of the polymer rather than the TFA salt. The chemical structures of the resulting polymers were confirmed by ${ }^{1} \mathrm{H}$ nuclear magnetic resonance (NMR) spectroscopy and infrared (IR) spectroscopy (Figures S1-S4). SEC confirmed that no significant changes in the molar masses of the polymers occurred during the functionalization or deprotection steps (Figure S5-S6). 

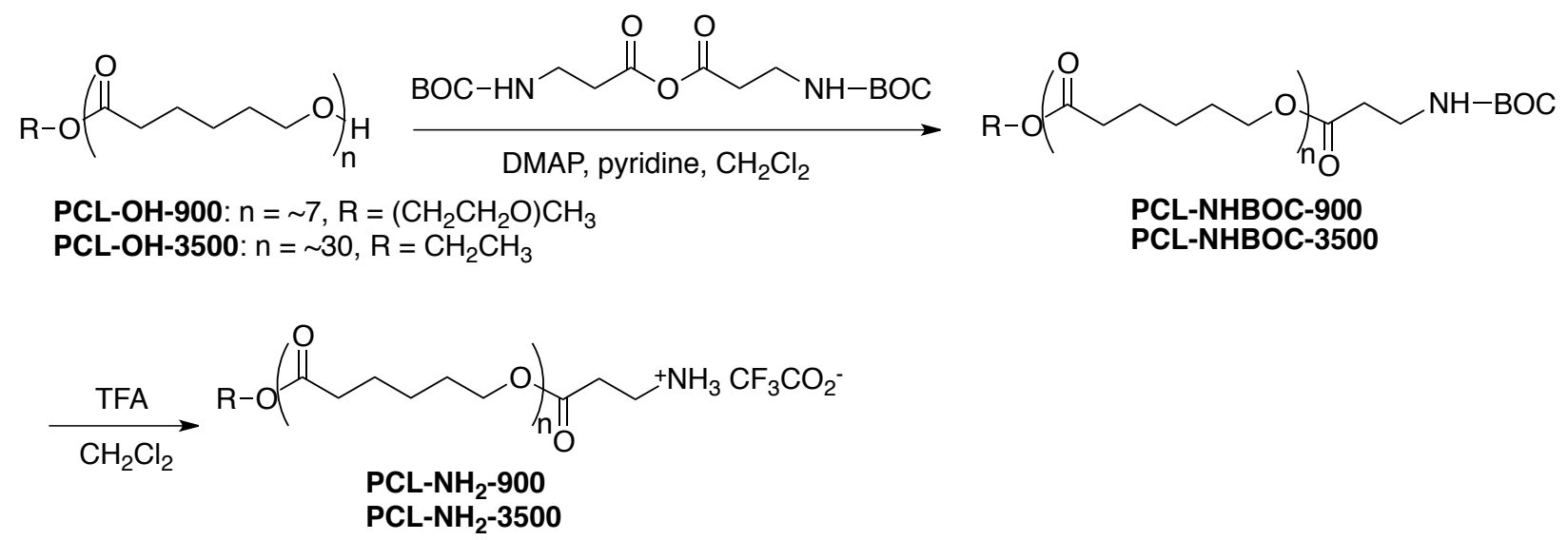

Scheme 1. Synthesis of amine-terminated PCL.<smiles>COCCOC(=O)C(C)O</smiles>

PDLLA-OH-2800<smiles>COCCOC(=O)C(C)OC(=O)CCNC(=O)OCc1ccccc1</smiles>

PDLLA-NHBOC-2800<smiles>CCCCOCCOC(=O)C(C)OC(=O)CCN</smiles>

PDLLA-NH ${ }_{2}-2800$

Scheme 2. Synthesis of amine-terminated PDLLA.

In preparation for the conjugation of the amine-terminated polyesters, 4-nitrophenyl carbonate-activated polyisobutylene (PIB-PNP, Scheme 3) was prepared as previously reported via epoxidation of butyl rubber having $2 \mathrm{~mol} \%$ of isoprene moieties, epoxide ring opening using $\mathrm{HCl}$ as a catalyst to afford an allylic alcohol, and then reaction of the resulting alcohols with 4nitrophenyl chloroformate. ${ }^{13}$ The amine-terminated polyesters were then reacted with PIB-PNP in toluene in the presence of DMAP at $60{ }^{\circ} \mathrm{C}$ overnight. The resulting graft copolymers were 
purified by washing an organic solution of the copolymer with water, followed by precipitation into acetone to remove byproducts, excess reagents, and ungrafted polyester chains. As shown in Table 1, the polyester content of the copolymers was tuned according to the molar mass of the polyester as well as the number of equivalents used in the grafting reaction.

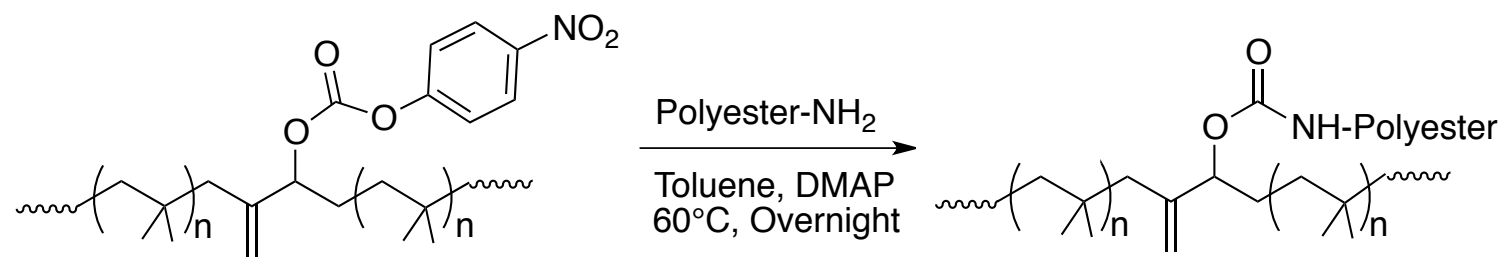

Scheme 3. Synthesis of PIB-polyester graft copolymers.

The graft copolymers were characterized chemically by ${ }^{1} \mathrm{H}$ NMR spectroscopy, IR spectroscopy, and SEC. As shown in Figure 1, consistent with our previous results involving the grafting of PEO,${ }^{14}$ conversion of the activated carbonates to carbamates upon successful grafting was characterized by ${ }^{1} \mathrm{H}$ NMR spectroscopy based on the upfield shifts of the peaks corresponding to the alkene protons (labeled a, $\mathrm{a}^{\prime}, \mathrm{b}$, and b' in Figure 1) as well as the allylic proton (labeled $\mathrm{c}$ and $\mathrm{c}^{\prime}$ in Figure 1). Whereas full conversion was obtained using 1.2 equivalents of polyester- $\mathrm{NH}_{2}$, the use of 0.8 equivalents led to $\sim 50 \%$ conversion (Table 1). The weight content of polyester was quantified based on the relative integrations of the peaks at $1.11 \mathrm{ppm}$ corresponding to the $\mathrm{CH}_{3}$ groups on PIB and either the triplet at either $4.1 \mathrm{ppm}$ corresponding to the $\mathrm{CH}_{2}$ adjacent to oxygen of the ester in PCL or the multiplet at $5.2 \mathrm{ppm}$ corresponding to the $\alpha$ CH group on PDLLA (Figures S7-S10). As shown in Table 1, the polyester content ranged from $15-44 \mathrm{wt} \%$ for PCL and was $28 \mathrm{wt} \%$ for the PDLLA graft copolymer. IR spectra of all of the graft copolymers had strong peaks at $2950 \mathrm{~cm}^{-1}$ corresponding to aliphatic $\mathrm{C}-\mathrm{H}$ stretching on both 
PIB and the polyester and at $1750 \mathrm{~cm}^{-1}$ corresponding to $\mathrm{C}=\mathrm{O}$ stretching on the polyester (Figures S11-S12). The molar masses of the graft copolymers could not be determined by SEC due to anomalous behavior of these PIB graft copolymers in SEC, which has been reported by our group and others. ${ }^{9,14}$ However SEC did confirm the absence of ungrafted polyester in the copolymers (Figures S13-S14).

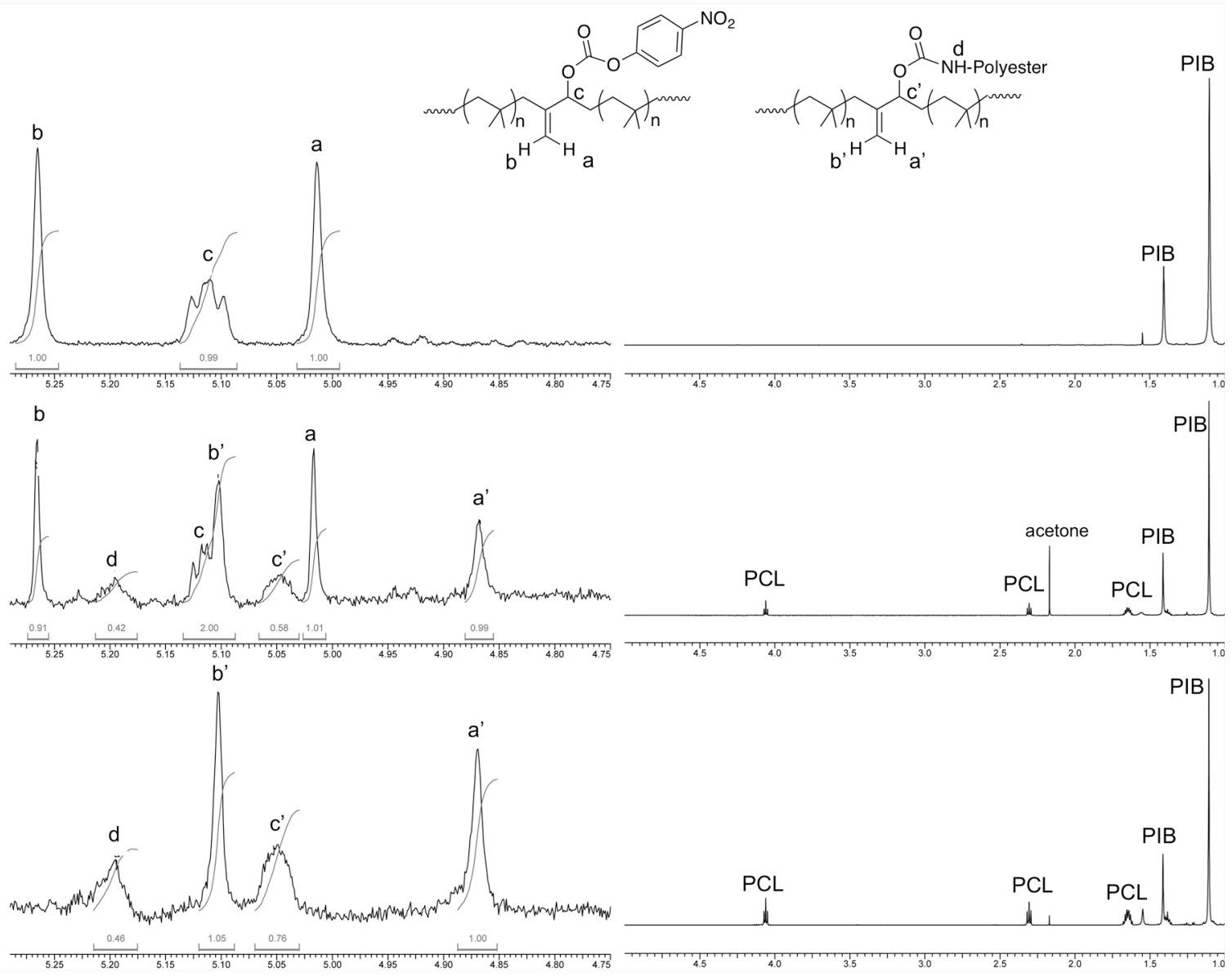

Figure 1. ${ }^{1} \mathrm{H}$ NMR spectra $\left(\mathrm{CDCl}_{3}, 600 \mathrm{MHz}\right)$ including a zoom on the region from 4.7 to 5.3 ppm of a) PIB-PNP; b) PIB-PCL-3500a; c) PIB-PCL-3500b. The spectra show partial conversion for PIB-PCL-3500a due to substoichiometric use of PCL-NH2-3500 relative to 4nitrophenyl carbonate groups versus full conversion for PIB-PCL-3500b due to the use of 1.2 equiv. of PCL-NH2-3500. 


\section{Physical characterization of the graft copolymers}

The thermal properties of the polymers were measured by DSC. The starting butyl rubber has a $\mathrm{T}_{\mathrm{g}}$ between -63 and $-70{ }^{\circ} \mathrm{C} .{ }^{53,54}$ PCL-OH-900 has no distinct $\mathrm{T}_{\mathrm{g}}$ due to its low molar mass, but a melting temperature $\left(\mathrm{T}_{\mathrm{m}}\right)$ of $44{ }^{\circ} \mathrm{C}$. Upon its incorporation into the graft copolymer PIB-PCL900, containing $15 \mathrm{wt} \% \mathrm{PCL}$, a $\mathrm{T}_{\mathrm{g}}$ of $-67^{\circ} \mathrm{C}$ was observed, likely corresponding to that of the PIB backbone. However, no $\mathrm{T}_{\mathrm{m}}$ was observed, suggesting that the PCL did not phase separate into crystalline domains. PCL-OH-3500 has a $\mathrm{T}_{\mathrm{g}}$ of $-64{ }^{\circ} \mathrm{C}$ and a $\mathrm{T}_{\mathrm{m}}$ of $63{ }^{\circ} \mathrm{C}$. Upon its incorporation into PIB-PCL-3500a, containing $32 \mathrm{wt} \% \mathrm{PCL}$, a $\mathrm{T}_{\mathrm{g}}$ of $-65^{\circ} \mathrm{C}$ and a $\mathrm{T}_{\mathrm{m}}$ of $44^{\circ} \mathrm{C}$ were observed. The $\mathrm{T}_{\mathrm{g}}$ is consistent with those of both the PIB and PCL, which are very similar, whereas the $T_{m}$ is lower than that of the pure PCL homopolymer. This suggests that phase separation of PCL occurred at the nanoscale but that the crystalline domains were likely smaller than those of the bulk polymer, resulting in a lower $\mathrm{T}_{\mathrm{m}}$. PIB-PCL-3500b having a higher PCL content of $44 \mathrm{wt} \%$ had a similar $\mathrm{T}_{\mathrm{g}}$ of $-62{ }^{\circ} \mathrm{C}$, but a higher $\mathrm{T}_{\mathrm{m}}$ of $50{ }^{\circ} \mathrm{C}$, suggesting it could phase separate and crystalline over larger domains. Overall, these results are in agreement with previous reports of linear block copolymers of PIB and PCL, where the incorporation of longer PCL blocks and higher PCL content resulted in $\mathrm{T}_{\mathrm{m}}$ values similar to those of the bulk PCL. ${ }^{10,49,55}$ The observation of $\mathrm{T}_{\mathrm{m}}$ values lower than those of the bulk semi-crystalline polymer for shorter polymer grafts and lower graft content is consistent with our previous observations for PIB-PEO graft copolymers. ${ }^{14}$ In the case of PDLLA, bulk PDLLA-OH-2800 is amorphous with a $T_{g}$ of 29 ${ }^{\circ} \mathrm{C}$. Upon its incorporation into PIB-PDLLA-2800, $\mathrm{TgS}$ of $-63{ }^{\circ} \mathrm{C}$ and $23{ }^{\circ} \mathrm{C}$ were observed. The observation of two $\mathrm{T}_{\mathrm{gS}}$ is consistent with phase separation of the copolymer blocks as was previously observed for linear PIB-PLLA multiblock copolymers. ${ }^{46}$ 
The phase separation in the graft copolymers was further probed through AFM imaging. Thin films of the copolymers were prepared by spin-coating a $3 \mathrm{wt} \%$ solution of copolymer in toluene onto silicon wafers. After complete drying, the samples were annealed by heating at 100 ${ }^{\circ} \mathrm{C}$ for 7 hours. Consistent with the thermal analysis, no phase separation was observed for PIBPCL-900 (Figure 2a). On the other hand, phase separation was observed for the other three graft copolymers (Figure 2b-d). In particular, PIB-PCL-3500b formed a well-ordered lamellar morphology, which is consistent with the close to 50:50 ratio of PIB:PCL. PIB-PCL-3500a and PIB-PCL-PDLLA appeared to form less ordered spherical and cylindrical morphologies. The corresponding topographical images are shown in Figure S16. For comparison, physical blends of PCL and PDLLA with butyl rubber in similar mass ratios to those of the block copolymers were also prepared and imaged by AFM. In each case, micrometer-scale phase separation was observed due to the incompatibility of the two polymers (Figures S17-S18). In the graft copolymers, covalent attachment constrains phase separation to the nanoscale dimensions of the polymers, which has the potential to improve the properties of the materials as described below. 
a)

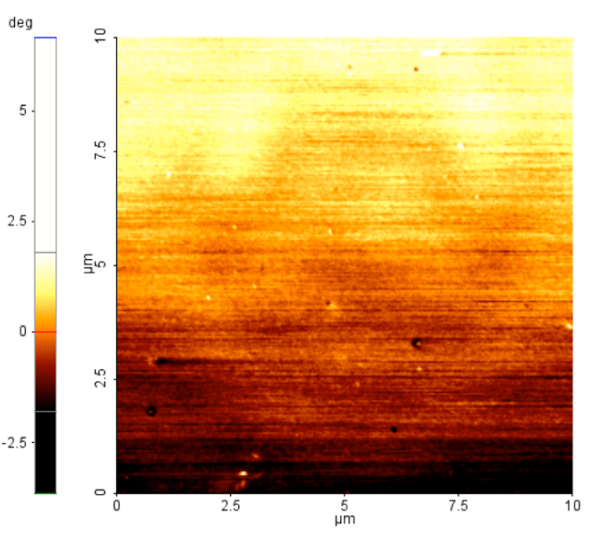

c)

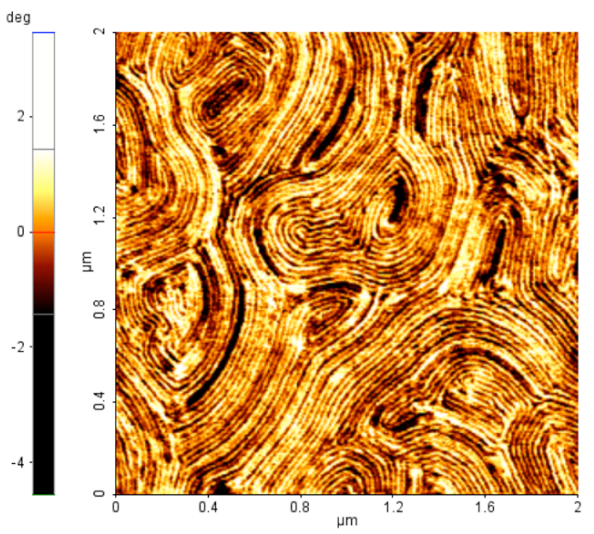

b) deg

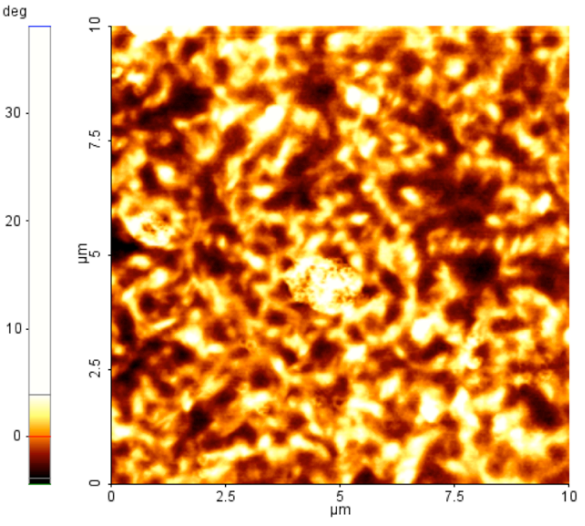

d) ${ }^{\operatorname{deg}}$

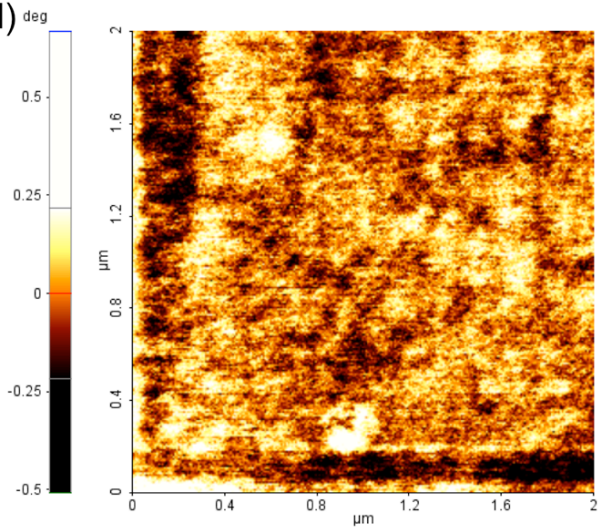

Figure 2. AFM phase images of a) PIB-PCL-900; b) PIB-PCL-3500a; c) PIB-PCL-3500b; d)

PIB-PDLLA-2800 following spin coating from toluene and annealing at $100{ }^{\circ} \mathrm{C}$ for 7 hours.

The wettability of a polymer surface is also important for many applications, so the water contact angles (WCAs) of the graft copolymer films prepared by spin-coating were measured using the sessile drop method. As shown in Table 2, the WCA of PCL-OH-900 $\left(51 \pm 2^{\circ}\right)$ was lower than that of PCL-OH-3500 $\left(71 \pm 1^{\circ}\right)$, likely due to the increased contribution from the hydrophilic terminal hydroxyl as well as the initiator. PDLLA-OH-2800 had a WCA of $66 \pm 2^{\circ}$. Upon grafting either PCL or PDLLA to the activated polyisobutylene, the contact angles of the copolymers ranged from $91-94^{\circ}$, very similar to that of the starting butyl rubber, which has a reported contact angle of $91^{\circ} .56$ This increase in contact angle relative to the polyesters can be 
attributed to the conversion of hydrophilic terminal groups on the polyester to carbamates in the graft copolymer, the relatively high PIB content of the graft copolymers, and the tendency of polymers to rearrange in order to present hydrophobic surfaces, thereby minimizing their surface energy. $^{57}$

\section{Tensile testing}

Uncross-linked butyl rubber exhibits a low ultimate tensile strength $(\sigma)$ of $\sim 0.09 \mathrm{MPa}$, a low Young's Modulus (E) of 0.2-0.5 MPa, but a high elongation $\left(\varepsilon_{\mathrm{b}}\right)$ at break of $\sim 800 \% .{ }^{58}$ On the other hand, PCL has a $\sigma$ of $\sim 4 \mathrm{MPa}, \mathrm{E}$ of $\sim 80 \mathrm{MPa}$, and $\varepsilon_{\mathrm{b}}$ of $\sim 60 \%$ and PDLLA has $\sigma$ of $\sim 40$ $\mathrm{MPa}, \mathrm{E}$ of $\sim 30 \mathrm{MPa}$, and an $\varepsilon_{\mathrm{b}}$ of $6-74 \% .{ }^{59-62}$ It was proposed that the incorporation of semicrystalline or glassy PCL and PDLLA blocks respectively would increase both the modulus and strength of the rubber. Therefore, the mechanical properties of the new graft copolymers were measured by tensile testing. Representative stress-strain curves are shown in Figure 3, while the mechanical properties are summarized in Table 3. The incorporation of $15 \mathrm{wt} \%$ of PCL in PIB-PCL-900 did not result in an increase in E, but it did result in an $\sim 2$-fold increase in the Young's modulus at $50 \%$ stain $\left(E_{50}\right)$, a 6-fold increase in $\sigma$ and a 1.6-fold increase in $\varepsilon_{b}$, suggesting that even small percentages of low molar mass PCL can toughen butyl rubber. The incorporation of 26 wt \% PCL in PIB-PCL-3500a resulted in small increases in $\mathrm{E}_{\text {and }} \mathrm{E}_{50}$ to 0.74 $\mathrm{MPa}$ and 1.10 MPa respectively relative to $\sim 0.6 \mathrm{MPa}$ for the starting rubber. The $\sigma$ of PIB-PCL3500a was similar to that of PIB-PCL-900 but $\varepsilon_{\mathrm{b}}$ was much lower than that of either the starting rubber or PIB-PCL-900. These differences can likely be attributed to the presence of crystalline PCL domains in PIB-PCL-3500a but not in PIB-PCL-900. Upon increasing the PCL content in

PIB-PCL-3500b, a further substantial increase in E to $22 \mathrm{MPa}$ was observed, which was 
accompanied by an increase in $\sigma$ to $3.9 \mathrm{MPa}$, which is 16 -fold higher than butyl rubber and a decrease in $\varepsilon_{b}$ to $170 \%$, which is $\sim 4$-fold less than butyl rubber. The incorporation of $28 \mathrm{wt} \%$ of PDLLA in PIB-PDLLA-2800 resulted in a E of 2.9 MPa, which is a 5-fold increase relative to butyl rubber, a $\sigma$ of $4 \mathrm{MPa}$, which is a 16-fold increase relative to butyl rubber, and a decrease in $\varepsilon_{\mathrm{b}}$ to $250 \%$. As supported by the thermal analyses described above, these changes in mechanical properties likely result from glassy domains of PDLLA within the rubber matrix.

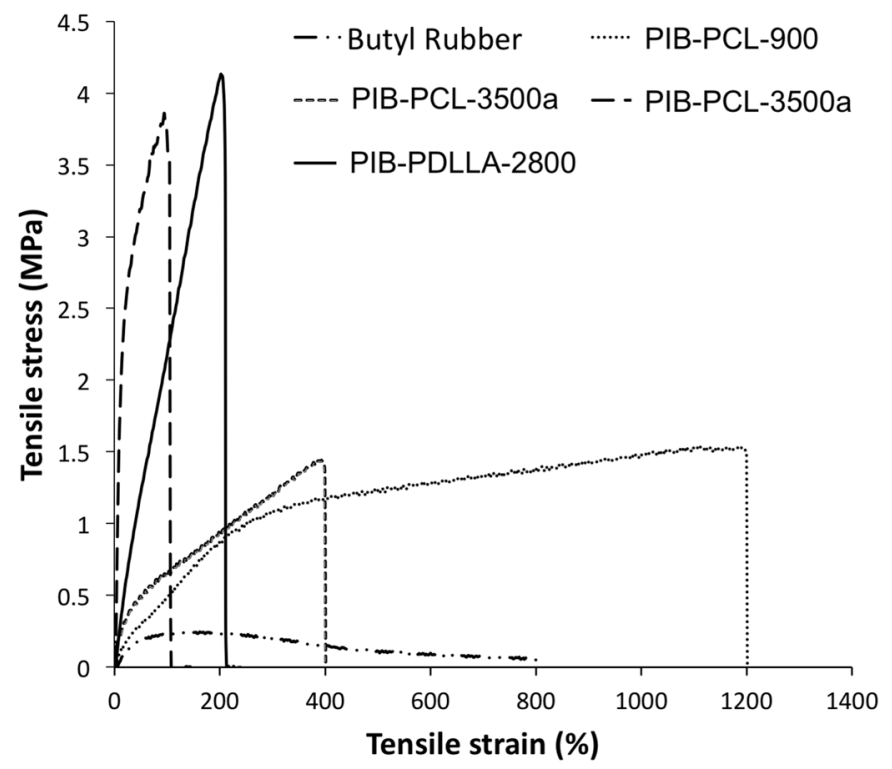

Figure 3. Representative strain-strain curves for the graft copolymers in comparison with butyl rubber.

Overall, with the exception of the high $\varepsilon_{b}$ observed for PIB-PCL-900, all of the graft copolymers exhibited properties intermediate between the two homopolymers and the properties could be readily tuned by varying the content of the glassy or semi-crystalline block. This behavior is similar to that previously observed for linear PIB-PLLA multiblock copolymers ${ }^{46}$ and suggests that PCL and PDLLA can impart cross-linking via micro-phase separation in butyl 
rubber. However, in comparison with the PIB-PLLA linear block copolymers, $\sigma$ and E were somewhat lower for the current materials. This might be attributed to the differences in thermal and mechanical properties of PCL and PDLLA with those of PLLA as well as the different architectures of the current polymers. In comparison with the well-studied thermoplastic elastomer SIBS, composed of $24 \mathrm{wt} \%$ PS, as well as a recently reported cross-linked version of SIBS, the E values for the current materials were comparable, but $\sigma$ was somewhat lower, which again can be attributed to the properties of polystyrene and the polymer architectures. ${ }^{63,64}$ The observed trends and the magnitudes of $\mathrm{E}, \sigma$, and $\varepsilon_{\mathrm{b}}$ were also similar to those of graft copolymers of butyl rubber with polystyrene and PEO grafts which are also glassy and semi-crystalline respectively. ${ }^{7,16}$

To confirm that the covalent copolymer structure was important in imparting the observed mechanical properties, physical blends of butyl rubber with PCL and PDLLA were also investigated. Representative stress-strain curves are provided in Figure S19. As shown in Table 3, E was relatively high for these blends, ranging from $\sim 2-5 \mathrm{MPa}$ for the PCL blends and $\sim 15 \mathrm{MPa}$ for the PDLLA blend. However, the sample variability was high, which can likely be attributed to poor sample homogeneity, as suggested by the AFM imaging described above. On the other hand, $\sigma$ was much lower for the blends than the graft copolymers in all cases, suggesting that the nanoscale rather than micrometer scale phase separation observed for the graft copolymers is important for their strength. As the tensile testing was performed on each blend, the samples appeared to fracture at the polyester domains or the rubber-polyester interface, and residual butyl rubber was pulled in the axial direction. The $\varepsilon_{\mathrm{b}}$ values for the blends were all lower than those of butyl rubber and scaled inversely with the polyester content. From these results, it can be 
concluded that the graft copolymers were superior in terms of their strength and homogeneity, which are important properties for many applications.

\section{Degradation study}

Both PCL and PDLLA are degradable polymers. Under physiological conditions (neutral pH, 37

${ }^{\circ} \mathrm{C}$ ), depending on the polymer's molar mass and the specimen's dimensions, PCL has been

found to degrade over a period of years, ${ }^{44}$ and PDLLA degrades over several months. ${ }^{41,65}$ On the other hand, butyl rubber exhibits high chemical stability, and typically exhibits little to no degradation over several years. ${ }^{1,2}$ To determine the scope of potential applications for the new graft copolymers, it was of interest to determine how the combination of these polymers with very different degradation properties would influence their degradation behavior. Films of the graft copolymers and homopolymer controls with $0.35 \mathrm{~mm}$ thickness were prepared by melt pressing, and disks $5 \mathrm{~mm}$ in diameter were punched and immersed in aqueous solution. As the degradation was expected to proceed very slowly, accelerated degradation conditions were used, involving the subjection of the samples to $5 \mathrm{M} \mathrm{NaOH}$ and $37^{\circ} \mathrm{C}$ for an 8 -week period. ${ }^{66,67}$

As shown in Figure 4, while the degradation of PCL and PDLLA to soluble species was complete within 1-3 days, butyl rubber exhibited $<1 \%$ mass loss over 8 weeks. When polyesters and butyl rubber were combined in the graft copolymers, $<1 \%$ mass loss was also observed. While it is possible that erosion of polyester on the surface of the disk occurred, this suggests that in the bulk the butyl rubber can protect the polyester from degradation, even under these harsh hydrolytic conditions. This can likely be attributed to the high impermeability of butyl rubber to water and hydroxide species. Observations of the disks at the macroscopic scale showed extensive wrinkling and contraction for butyl rubber as well as PIB-PCL-900 and PIB-PCL- 
3500a, presumably due to creep deformation in the aqueous environment (Figure S20). On the other hand, PIB-PCL-3500b and PIB-PDLLA-2800, containing higher percentages of the semicrystalline and glassy polyesters respectively retained their shape, suggesting that the polyester domains provide physical cross-linking that reduces creep, allowing the polymers to retain their shape. The surfaces of the disks were also imaged by scanning electron microscopy prior to immersion in aqueous $\mathrm{NaOH}$ and after 8 weeks (Figure 5). PIB-PCL-900 and PIB-PCL-3500a exhibited increased surface roughness after 8 weeks, which was consistent with the observed wrinkling behavior. PIB-PCL-3500b and PIB-PDLLA-2800 increased in roughness to a much smaller extent, which suggests erosion of surface polyester domains or a small degree of surface wrinkling. However, consistent with the lack of mass loss, no cracking and no significant erosion were observed by SEM.

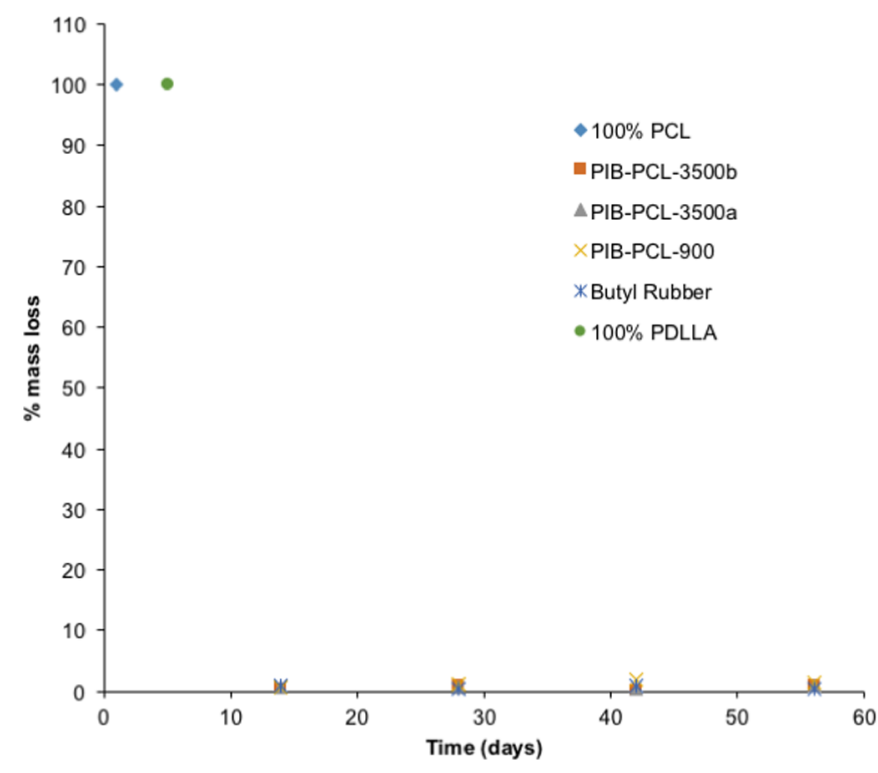

Figure 4. Mass loss from graft copolymer and the corresponding homopolymer disks following incubation in $5 \mathrm{M} \mathrm{NaOH}$ at $37^{\circ} \mathrm{C}$ for 8 weeks. 

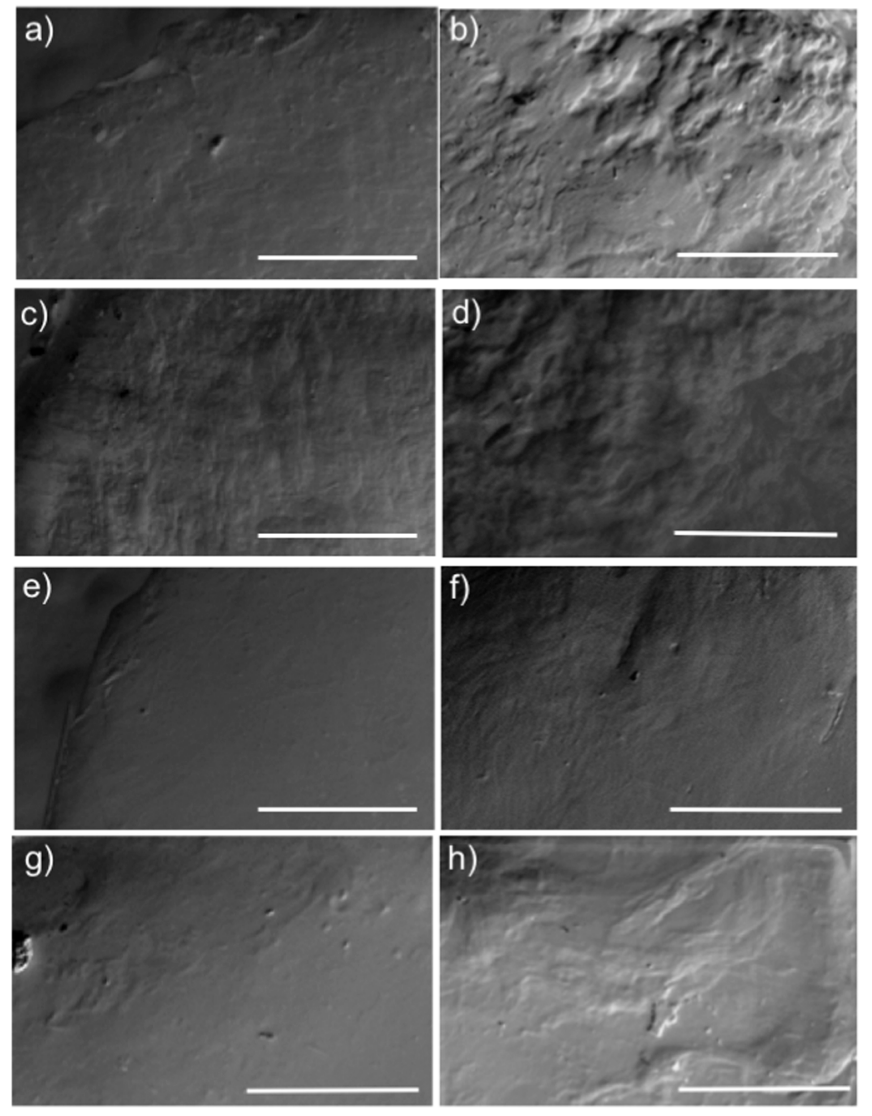

Figure 5. SEM images of disk surfaces before (left column) and after 8 weeks immersion in $5 \mathrm{M}$ $\mathrm{NaOH}$ at $37^{\circ} \mathrm{C}$ for 8 weeks. a-b) PIB-PCL-900; c-d) PIB-PCL-3500a; e-f) PIB-PCL-3500b; gh) PIB-PDLLA-2800. Scale bar $=500 \mu \mathrm{m}$.

The hydrolytic degradation of linear PIB-PLLA multiblock copolymers has also been previously investigated. ${ }^{47}$ More rapid degradation was observed for copolymers with shorter PLLA blocks due to their lower crystallinity. However, their samples exhibited $10-100 \%$ mass loss over 20 - 30 weeks, even in $\mathrm{pH} 7.4$ buffer at $37^{\circ} \mathrm{C}$, suggesting more rapid erosion. While the molar mass of the polyester grafts and overall polyester content of the materials in our current work is comparable to those of the previously studied multiblock copolymers, a key difference is the graft copolymer architecture of the current materials and the much longer PIB backbone 
length of $200-400 \mathrm{~kg} \mathrm{~mol}^{-1}$ in comparison with $3400 \mathrm{~g} \mathrm{~mol}^{-1}$ in the previous system. The higher molar mass of the PIB backbone, its organization in the solid state, and its impermeability to water must allow it to organize in a manner that effectively shields the internal polyester domains from erosion. In contrast, the shorter PIB domains in the linear multiblock domains appear to be incapable of protecting the PLLA from erosion. This demonstrates the importance of PIB molar mass and overall polymer architecture in the properties of these materials. While enhanced erosion of these graft copolymer materials relative to butyl rubber would ultimately be expected over the long term, the current study suggests that polyesters can be used to enhance the modulus and strength of butyl rubber for applications while at the same time preserving good stability and chemical resistance.

\section{Conclusions}

Amine-terminated PCL and PDLLA were synthesized and then a "grafting-to" synthetic approach starting from butyl rubber was used to prepare PIB-polyester graft copolymers. The polyester content was varied by tuning both the molar mass of the polyester and the number of equivalents used in the grafting reaction. Thermal analysis and AFM imaging suggested that phase separation occurred for the PIB-PDLLA copolymer prepared from $2800 \mathrm{~g} \mathrm{~mol}^{-1}$ PDLLA and for the PIB-PCL copolymer prepared from $3500 \mathrm{~g} \mathrm{~mol}^{-1} \mathrm{PCL}$ but not from $900 \mathrm{~g} \mathrm{~mol}^{-1}$ PCL. Tensile testing showed a trend towards increased Young's modulus, increased $\sigma$, and decreased $\varepsilon_{\mathrm{b}}$ with increasing polyester content. The graft copolymers exhibited better mechanical properties than the corresponding blends prepared from similar polyester content, suggesting that the nanoscale phase separation occurring for the copolymers was important for their mechanical properties. The degradation of the materials in $5 \mathrm{M} \mathrm{NaOH}$ was also studied and it was found that 
despite the high polyester content of some of the materials, no significant mass loss was observed. These results suggest that polyester grafts can be onto butyl rubber in order to tune its properties for different applications, while still preserving the high stability of butyl rubber. The use of polyester grafts rather than chemical cross-linking approaches may be particularly useful for biomedical applications as polyesters have already been demonstrated to be biocompatible in a number of medical devices such as screws, plates, sutures and drug delivery vehicles.

\section{Acknowledgements}

The authors thank LANXESS Inc., the Natural Sciences and Engineering Research Council of Canada, the Government of Ontario (OGS scholarship to BT), and the Canada Research Chair Program for funding this work. LANXESS Inc. is thanked for kindly providing all of the rubber starting materials. Dr. Heng-Yong Nie at Surface Science Western is acknowledged for assistance with the AFM measurements.

\section{Supporting information}

NMR spectra, IR spectra, SEC traces, DSC thermograms, additional AFM images, stress-strain curves for polymer blends, and digital photographs of polymer disks during the degradation study.

\section{References}

1. Greve H-H and Threadingham D in Ullmann's Encyclopedia of Industrial Chemistry, Vol. 31, Wiley-VCH Verlag GmbH \& Co. KGaA, Weinheim, pp 579-582 (2000). 
2. Threadingham D, Obrecht W, Wieder W, Wachholz G and Engehausen R in Ullmann's Encyclopedia of Industrial Chemistry, Vol. 31, Wiley-VCH Verlag GmbH \& Co. KGaA, Weinheim, pp 597-622 (2000).

3. Shanmugam KVS, Parent JS and Whitney RA, Ind Eng Chem Res 51: 8957-8965 (2012).

4. Puskas JE, Kaszas G, Chen CC and Kennedy JP, Polym Bull 20: 253-260 (1988).

5. Morrison NJ and Porter M, Rubb Chem Technol 57: 63-85 (1984).

6. Wu W, Karamdoust S, Turowec BA and Gillies ER, Eur Polym J 49: 4238-4248 (2013).

7. Abd Rabo Moustafa MM and Gillies ER, Macromolecules 46: 6024-6030 (2013).

8. Polgar LM, van Duin M, Broekhuis AA and Picchioni F, Macromolecules 48: 7096-7105 (2015).

9. Yamashita S, Kodama K, Ikeda Y and Kohjiya S, J Polym Sci Part A: Polym Chem 31: 24372444 (1993).

10. McLean JK, Guillen-Castellanos SA, Parent JS, Whitney RA and Resendes R, Eur Polym J 43: 4619-4627 (2007).

11. McLean JK, Guillen-Castellanos SA, Parent JS, Whitney RA, Kulbaba K and Osman A, Ind Eng Chem Res 48: 10759-10764 (2009).

12. Parent JS, Malmberg S, McLean JK and Whitney RA, Eur Polym J 46: 702-708 (2010).

13. Bonduelle CV and Gillies ER, Macromolecules 43: 9230-9233 (2010).

14. Bonduelle CV, Karamdoust S and Gillies ER, Macromolecules 44: 6405-6415 (2011).

15. Karamdoust S, Bonduelle CV, Amos RC, Turowec B, Ferrari L and Gillies ER, J Polym Sci Part A: Polym Chem 51: 3383-3394 (2013).

16. Karamdoust S, Crewdson P, Ingratta M and Gillies ER, Polym Int 64: 611-620 (2015).

17. Fónagy T, Iván B and Szesztay M, Macromol Rapid Commun 19: 479-483 (1998). 
18. Kali G, Vavra S, László K and Iván B, Macromolecules 46: 5337-5344 (2013).

19. Kennedy JP and Richard GC, Macromolecules 26: 567-571 (1993).

20. Haraszti M, Tóth E and Iván B, Chem Mater 18: 4952-4958 (2006).

21. Cao X and Faust R, Macromolecules 32: 5487-5494 (1999).

22. Sipos L, Cao X and Faust R, Macromolecules 34: 456-459 (2001).

23. Antony P, Kwon Y, Puskas JE, Kovar M and Norton PR, Eur Polym J 40: 149-157 (2003).

24. Antony P, Puskas JE and Kontopoulou M, Polym Eng Sci 43: 243-253 (2003).

25. El Fray M, Prowans P, Puskas JE and Altsta V, Biomacromolecules 7: 844-850 (2006).

26. Kwee T, Taylor SJ, Mauritz KA and Storey RF, Polymer 46: 4480-4491 (2005).

27. Storey RF, Baugh DW and Choate KR, Polymer 40: 3083-3090 (1999).

28. Storey RF, Scheuer AD and Achord BC, Polymer 46: 2141-2152 (2005).

29. Kopchick JG, Storey RF, Jarrett WL and Mauritz KA, Polymer 49: 5045-5052 (2008).

30. Kucera LR, Brei MR and Storey RF, Polymer 54: 3796-3805 (2013).

31. Kwon Y, Faust R, Chen CX and Thomas EL, Macromolecules 35: 3348-3357 (2002).

32. Higashihara T, Feng D and Faust R, Macromolecules 39: 5275-5279 (2006).

33. Mageneau AJD, Martinez-Castron N, Savin DA and Storey RF, Macromolecules 42: 80448051 (2009).

34. Kang J, Erdodi G and Kennedy JP, J Polym Sci, Part A: Polym Chem 49: 3891-3904 (2011).

35. Kulkarni P, Ojha U, Wei X, Gurung N, Seethamraju K and Faust R, J Appl Polym Sci 130: 891-897 (2013).

36. Gergely AL and Puskas JE, J Polym Sci, Part A: Polym Chem 53: 1567-1574 (2015).

37. Puskas JE, Gergely AL and Kaszas G, J Polym Sci, Part A: Polym Chem 51: 29-33 (2013). 
38. Pinchuk L, Wilson GJ, Barry JJ, Schoephoersterd RT, Parele J-M and Kennedy JP, Biomaterials 29: 448-460 (2008).

39. Puskas JE, Munoz-Robledo LG, Hoerr RA, Foley J, Schmidt SP, Evancho-Chapman M, Dong J, Frethem C and Haugstad G, Wiley Interdiscip Rev: Nanomed Nanobiotechnol 1: 451-462 (2009).

40. Sheriff J, Claiborne TE, Tran PL, Kothadia R, George S, Kato YP, Pinchuk L, Slepian MJ and Bluestein D, ACS Appl Mater Interfaces 7: 22058-22066 (2015).

41. Okada M, Prog Polym Sci 27: 87-133 (2002).

42. Vert M, Prog Polym Sci 32: 755-761 (2007).

43. Rathi SR, Coughlin EB, Hsu SL, Golub CS, Ling GH and Tzivanis MJ, Polymer 53: 30083016 (2012).

44. Woodruff MA and Hutmacher DW, Prog Polym Sci 35: 1217-1256 (2010).

45. Shao J, Sun JR, Bian XC, Cui Y, Li G and Chen XS, J Phys Chem B 116: 9983-9991 (2012).

46. Ohja U, Kulkarni P, Singh J and Faust R, J Polym Sci, Part A: Polym Chem 47: 3490-3505 (2009).

47. Ohja U, Kulkarni P, Cozzens D and Faust R, J Polym Sci, Part A: Polym Chem 48: 3767$3774(2010)$.

48. Gorda KR, Peiffer DG, Chung TC and Berluche E, Polym Commun 31: 286-289 (1990).

49. Kim MS and Faust R, Polym Bull 48: 127-134 (2002).

50. Castano M, Alvarez A, Becker ML and Puskas JE, eXPRESS Polym Lett 10: 693-700 (2016).

51. Storey RF, Brister LB and Sherman JW, J Macromol Sci, Part A: Pure Appl Chem A38: 107-122 (2001).

52. Li B, Martin A and Gillies ER, Chem Commun 5217-5219 (2007). 
53. Studies in Polymer Science, 1: Elastomers and Rubber Compounding Materials, ed by Franta I, Elsevier, New York (1989).

54. Willenbacher N and Lebedeva O in Handbook of Pressure Sensitive Adhesives and Products, ed by Benedek I and Feldstein MM. Taylor and Francis Group, Boca Raton, pp 4.1-4.18 (2009). 55. Ostas E, Schröter K, Beiner M, Yan T, Thurn-Albrecht T and Binder WH, J Polym Sci, Part A: Polym Chem 49: 3404-3416 (2011).

56. Bonduelle CV, McEachran MJ, Karamdoust S and Gillies ER, J Coatings Technol Res 10: 733-742 (2013).

57. Kim JD, Chaudhury MK, Owen MJ and Orbeck T, J Colloid Interface Sci 244: 200-207 (2001).

58. Ikeda Y, Kodama K, Kajiwara K and Kohjiya S, J Polym Sci, Part B: Polym Physics 33: 387-394 (1995).

59. Engelberg I and Kohn J, Biomaterials 12: 292-304 (1991).

60. Harte I, Birkinshaw C, Jones E, Kennedy JP and Debarra E, J Appl Polym Sci 127: 1997$2003(2013)$.

61. Ji C, Annabi N, Hosseinkhani M, Sivaloganathan S and Dehghani F, Acta Biomater 8: 570$578(2012)$.

62. Pok S, Myers JD, Madihally SV and Jacot JG, Acta Biomater 9: 5630-5642 (2013).

63. Puskas JE, Antony P, El FM and Altstadt V, Eur Polym J 39: 2041-2049 (2003).

64. Strickler F, Richard R, McFadden S, Lindquist J, Schwarz MC, Faust R, Wilson GJ and Boden M, J Biomed Mater Res, Part A 92A: $773-782$ (2010).

65. Hayashi T, Prog Polym Sci 19: 663-702 (1994).

66. Htay AS, Teoh SH and Hutmacher DW, J Biomater Sci, Polym Ed 15: 683-700 (2004). 
67. Cam D, Hyon S-H and Ikada Y, Biomaterials 16: 833-843 (1995). 
Table 1. Content and properties of PIB-polyester graft copolymers.

\begin{tabular}{|l|l|l|l|l|l|l|}
\hline Copolymer & Polyester- & Equiv. of & Functionalized & Polyester & $\mathrm{T}_{\mathrm{g}}$ & $\mathrm{T}_{\mathrm{m}}$ \\
& $\mathrm{NH}_{2}$ & polyester- & Isoprene Units & Content & $\left({ }^{\circ} \mathrm{C}\right)$ & $\left({ }^{\circ} \mathrm{C}\right)$ \\
\hline PIB-PCL-900 & PCL-900 & 1.2 & $>99$ & 15 & & \\
\hline PIB-PCL-3500a & PCL-3500 & 0.8 & 50 & 26 & -65 & 44 \\
\hline PIB-PCL-3500b & PCL-3500 & 1.2 & $>99$ & 44 & -62 & 50 \\
\hline PIB-PDLLA-2800 & PDLLA- & 1.2 & $>99$ & 28 & -63, & none \\
& 2800 & & & & 23 & \\
\hline
\end{tabular}

Table 2. Water contact angles of graft copolymers and the corresponding homopolymers.

\begin{tabular}{|l|l|}
\hline Homopolymer/Copolymer & Contact Angle $\left(^{\circ}\right)$ \\
\hline PCL-OH-900 & $51 \pm 2$ \\
\hline PCL-OH-3500 & $71 \pm 1$ \\
\hline PDLLA-OH-2800 & $66 \pm 2$ \\
\hline PIB-PCL-900 & $92 \pm 1$ \\
\hline PIB-PCL-3500a & $92 \pm 2$ \\
\hline PIB-PCL-3500b & $94 \pm 1$ \\
\hline PIB-PDLLA-2800 & $91 \pm 2$ \\
\hline
\end{tabular}


Table 3. Tensile properties of graft copolymers and polymer blends.

\begin{tabular}{|c|c|c|c|c|c|}
\hline Copolymer/blend & $\begin{array}{l}\text { Polyester } \\
\text { wt } \%\end{array}$ & $\begin{array}{l}\text { Young's } \\
\text { modulus (E), } \\
\mathrm{MPa}\end{array}$ & $\begin{array}{l}\text { Young's } \\
\text { modulus at } \\
50 \% \quad \text { strain } \\
\left(\mathrm{E}_{50}\right), \mathrm{MPa}\end{array}$ & $\begin{array}{l}\text { Ultimate } \\
\text { tensile } \\
\text { strength }(\sigma) \text {, } \\
\mathrm{MPa}\end{array}$ & $\begin{array}{l}\text { Elongation at } \\
\text { break }\left(\varepsilon_{b}\right), \%\end{array}$ \\
\hline Butyl rubber & 0 & $0.56 \pm 0.12$ & $0.66 \pm 0.19$ & $0.25 \pm 0.01$ & $740 \pm 200$ \\
\hline PIB-PCL-900 & 15 & $0.47 \pm 0.06$ & $1.1 \pm 0.4$ & $1.5 \pm 0.2$ & $1220 \pm 180$ \\
\hline PIB-PCL-3500a & 26 & $0.74 \pm 0.15$ & $1.1 \pm 0.3$ & $1.2 \pm 0.1$ & $450 \pm 65$ \\
\hline PIB-PCL-3500b & 44 & $22 \pm 6$ & $10 \pm 1$ & $3.9 \pm 1.0$ & $170 \pm 30$ \\
\hline $\begin{array}{l}\text { PIB-PDLLA- } \\
2800\end{array}$ & 30 & $2.9 \pm 0.4$ & $3.1 \pm 0.5$ & $4.0 \pm 0.9$ & $250 \pm 50$ \\
\hline $\begin{array}{l}\text { Butyl rubber/PCL } \\
\text { blend }\end{array}$ & 15 & $1.8 \pm 1.6$ & $0.79 \pm 0.15$ & $0.28 \pm 0.04$ & $520 \pm 110$ \\
\hline $\begin{array}{l}\text { Butyl rubber/PCL } \\
\text { blend }\end{array}$ & 32 & $2.3 \pm 2.2$ & $0.95 \pm 0.18$ & $0.18 \pm 0.03$ & $270 \pm 80$ \\
\hline $\begin{array}{l}\text { Butyl rubber/PCL } \\
\text { blend }\end{array}$ & 44 & $5.3 \pm 2.3$ & $1.2 \pm 0.1$ & $0.18 \pm 0.043$ & $140 \pm 50$ \\
\hline $\begin{array}{l}\text { Butyl rubber/ } \\
\text { PDLLA blend }\end{array}$ & 30 & $15 \pm 5$ & NA & $0.62 \pm 0.06$ & $250 \pm 70$ \\
\hline
\end{tabular}

